\title{
ESTRATIGRAFIA DE SEQUÊNCIAS DO INTERVALO APTIANO AO ALBIANO NA BACIA DO ARARIPE, NE DO BRASIL
}

\author{
Fábio Enrique Malagón Rojas \\ Orientador: Dra. Valéria Centurion Córdoba (UFRN) \\ 122 p. - Dissertação (Mestrado) - Defesa 27.02.2009
}

RESUMO. 0 presente trabalho tem como objetivo principal realizar uma análise estratigráfica detalhada do intervalo Aptiano ao Albiano na parte leste da Bacia do Araripe, NE do Brasil, o qual corresponde, litoestratigraficamente, às formações Rio da Batateira, Crato, Ipubí e Romualdo. A análise estratigráfica envolveu três etapas distintas, a análise 1D, 2D e 3D, nas quais foram adaptados os conceitos da estratigrafia de sequências visando elaborar um arcabouço de caráter cronoestratigráfico para a porção estudada da bacia. Tal estudo contou com uma base de dados integrada por informações de campo e de poços pertencentes ao projeto Santana, realizado pelo Ministério de Minas e Energia - DNPM - CPRM, nos anos de 1977 e 1978. A análise 1D, que envolveu a análise individual de cada afloramento e poço, permitiu o reconhecimento de 13 fácies sedimentares, individualizadas com base principalmente nas litologias predominantes e nas estruturas sedimentares. Tais fácies são representadas litologicamente por conglomerados, arenitos, pelitos, calcários, margas e evaporitos. As mesmas se associam de forma a caracterizar diferentes sistemas deposicionais, que integram desde o ambiente continental (sistemas fluvial e lacustre), ambiente parálico (sistemas deltaico e lagunar) até 0 ambiente marinho (sistema plataformal). 0 primeiro deles, 0 sistema fluvial, foi dividido em dois subtipos: 0 sistema fluvial meandrante, caracterizado por depósitos de preenchimento de canal e depósitos de planície de inundação, e o sistema fluvial entrelaçado formado principalmente por depósitos de preenchimento de canal; as fácies deste sistema se associam verticalmente segundo ciclos de afinamento textural para o topo (padrão em sino nos perfis geofísicos). 0 sistema lacustre, relacionado principalmente aos litótipos da Formação Crato, apresenta uma boa distribuição na bacia, sendo composto por depósitos de pelitos verdes e calcários laminados. 0 sistema deltaico é representado por depósitos de prodelta e de frente deltaica, os quais se dispõem verticalmente em ciclos com granocrescência para o topo (padrão em sino invertido nos perfis geofísicos). 0 sistema lagunar caracteriza-se pela presença de depósitos de anidrita e gipsita, além dos depósitos de pelitos negros com restos vegetais, os quais não contêm uma fauna tipicamente marinha. 0 sistema de plataforma marinha é composto por sucessões de pelitos pretos e cinza com faunas fossilíferas de Dinoflagelados (gêneros Spiniferites Mantell, Subtilisphaera Jain e Subtilisphaera Millipied), típicas deste tipo de sistema deposicional. As fácies sedimentares descritas se arranjam verticalmente de forma a compor ciclos com padrões de empilhamento progradacional, os quais formam ciclos com engrossamento textural para 0 topo, e retrogradacional, representados por ciclos com afinamento textural para o topo. Com base nestes ciclos, em seus padrões de empilhamento e na mudança verticais entre estes padrões, foram reconhecidos os tratos de sistemas e as sequências deposicionais. Os tratos de sistemas de Nível Baixo e 0 de Nível Alto são compostos por ciclos com padrão de empilhamento progradacional; o Trato de Sistemas Transgressivo, por sua vez, é formado por ciclos com padrão de empilhamento retrogradacional. A análise estratigráfica 2D foi elaborada por meio da realização de duas seções estratigráficas. Para a escolha do datum foi privilegiada a superfície de máxima inundação mais basal, interna à Sequência 1. A elaboração destas seções possibilitou compreender o comportamento de seis sequências deposicionais ao longo da área de estudo, as quais foram interpretadas como ciclos de segunda ordem ou superciclos (ciclos com durações entre 3 e $10 \mathrm{Ma}$ ), segundo a classificação de Vail et al. (1977). A Sequência 1, mais antiga das seis sequências identificadas, é composta pelos tratos de sistemas de Nível Baixo, Transgressivo e de Nível Alto. Os dois primeiros tratos são formados exclusivamente pelos depósitos fluviais da Formação Rio da Batateira, ao passo que o terceiro inclui depósitos deltaicos e lacustres da Formação Crato. As sequências 2 e 3 são formadas pelos tratos de sistemas Transgressivo (TST; fase de expansão do lago) e de Nível Alto (TSNA; fase retração do lago). Os TST's destas sequências são formados por depósitos lacustres, ao passo que os TSNA's contêm depósitos deltaicos, indicando assim condições de alta taxa de suprimento sedimentar na época da deposição deste. A Sequência 4 é formada pelos tratos de sistemas de Nível Baixo (TSNA), Transgressivo e de Nível Alto. 0 TSNB registra uma queda importante do nível base do lago; este trato se desenvolveu em condições de baixa razão entre a taxa de criação de espaço de acomodação e a taxa de influxo sedimentar. 0 TST marca a terceira fase de expansão do sistema lacustre na seção pós rifte da bacia; o sistema lacustre implantado no trato anterior inicia uma fase de retração em condições em que a taxa de aporte sedimentar passa a suplantar a de criação de espaço de acomodação. A Sequência 5 desenvolveu-se em duas fases distintas. A primeira relaciona-se com a última etapa de expansão do lago, (TST), trato basal desta sequência. Nesta fase, o nível base do lago subiu consideravelmente. A segunda fase, relacionada ao TSNA), indica o final do domínio lacustre na Bacia do Araripe e a mudança para sistemas lagunares e de planície de maré, com grande desenvolvimento das porções de supramaré. Estes sistemas eram formados por lagunas restritas, com lâmina de água rasa, e com conexão intermitente com o mar. Esta foi a fase em que a Bacia do Araripe registrou as mais severas condições de aridez de todo intervalo estudado, Aptiano ao Albiano, condições estas que propiciaram a formação de depósitos evaporíticos. A Sequência 6 iniciou sua deposição após uma queda significativa do incipiente mar (TSNB). Esta sequência é, indubitavelmente, a que contém os depósitos que comprovam a efetiva entrada do mar na Bacia do Araripe. 0 TST, trato final desta sequência, representa 0 momento em que o nível do mar atingiu 0 seu máximo durante todo 0 intervalo Aptiano ao Albiano. A análise estratigráfica do intervalo Aptiano ao Albiano permitiu compreender que o controle principal no desenvolvimento das sequências deposicionais reconhecidas na Bacia do Araripe foram às variações do nível de base local, as quais são controladas, por sua vez, pelas mudanças climáticas. 
ABSTRACT. This study has as a main objective to make a detailed stratigraphic analysis of the Aptian - Albian interval in the east part of Araripe Basin, NE of Brazil which correspond, litostratigraphically, to Rio da Batateira, Crato, Ipubi and Romualdo formations. The stratigraphic analysis was based on three different stages, the 1D, 2D and 3D analysis; these ones were adapted to the sequence stratigraphy concepts in order to create a chronostratigraphic framework for the study area within the basin. The database used in the present study contains field and well information, wells that belong to Santana Project, carried out by the Ministério de Minas e Energia - DNPM - CPRM from 1977 to 1978. The analysis 1D, which was done separately for each well and outcrop allowed the recognition of 13 sedimentary facies, mainly divided based on predominant lithologies and sedimentary structures. Such facies are lithologically represented by pebble, sandstones, claystones, margas and evaporates; these facies are associated in order to characterize different depositional systems, that integrate from the continental environment (fluvial system and lacustre), paralic system (delta system and lagunar) to the marine environment (shelf environment). The first one, the fluvial system was divided into two subtypes: meandering fluvial system, characterized by fill channel and floodplain deposits; the facies of this system are associated vertically according to the textural thinning upward cycles (dirtingup trend pattern in well logs). Lacustrine environment is mainly related with the lithotypes of the Crato Formation, it shows a good distribution within the basin, been composed by green claystone deposits and calcareous laminated. Deltaic System represented by prodelta and delta front deposits which coarsening upward tendency. Lagunar system is characterized by the presence of anhydrite and gypsum deposits besides the black claystone deposits with vegetal fragments which do not contain a fauna typically marine. The marine platform system is composed by successions of black and gray claystone with fossiliferous fauna of Dinoflagellates ( Spiniferites Mantell, Subtilisphaera Jain and Subtilisphaera Millipied genre) typical of this kind of depositional system. The sedimentary facies described are vertically arranged in cycles with progradational patterns which form textural coarsening upward cycles and retrogradational, represented by textural thinning downward cycles. Based in these cycles, in their stack pattern and the vertical change between these patterns, the systems tracks and the depositional sequences were recognized. The Low System Track (LST) and High System Track (HST) are composed by cycles with progradational stack pattern, whereas the Transgressive System Track (TST) is composed by retrogradational stack pattern cycles. The 2D stratigraphic analysis was done through the carrying out of two stratigraphic sections. For the selection of the datum the deepest maximum flooding surface was chosen, inside the Sequence 1, the execution of these sections allowed to understand the behaviour of six depositional systems along the study area, which were interpreted as cycles of second order or supercycles (cycles between 3 and $10 \mathrm{Ma}$ ), according to the Vail et al. (1977) classification. The Sequence 1, the oldest of the six identified is composed by the low, transgressive and high systems tracks. The first two system tracks are formed exclusively by fluvial deposits of the Rio da Batateira Formation whereas the third one includes deltaic and lacustrine deposits of the Crato Formation. The sequences 2 and 3 are formed by the transgressive systems tracks (lake spreading phase) and the highstand system track (lake backward phase). The TST of these sequences are formed by lacustrine deposits whereas HST contains deltaic deposits, indicating high rates of sedimentary supply at the time of it's deposition. The Sequence 4 is composed by LST, TST and HST, The TST4 shows a significant fall of the lake base level, this track was developed in conditions of low relation between the creation rate of space of accommodation and the sedimentary influx. The TST4 marks the third phase of expansion of the lacustrine system in the section after the basin's rift, the lacustrine system established in the previous track starts a backward phase in conditions that the sedimentary supply rate exceeds the creation rate of space accommodation. The Sequence 5 was developed in two different phases, the first one is related with the latest expansion stage of the lake, (TST5), the basal track of this sequence. In this phase the base level of the lake rose considerably. The second phase (related to the TST5) indicates the end of the lacustrine domain in the Araripe Basin and the change to lagunar system ant tidal flat, with great portions in the supratidal. These systems were formed by restricted lagoons, with shallow level of water and with intermittent connections with the sea. This, was the phase when the Araripe Basin recorded the most several arid conditions of the whole interval studied, Aptian - Albian, conditions that allow the formation of evaporitic deposits. The Sequence 6 began its deposition after a significant fall of the sea (LST6). The Sequence 6 is without any doubtlessly, the sequence that has deposits that prove the effective entrance of the sea into the Araripe Basin. The TST6, end of this sequence, represents the moment which the sea reaches its maximum level during the Aptian - Albian time. The stratigraphic analysis of the Aptian - Albian interval made possible the understanding that the main control in the development of the depositional sequences recognized in the Araripe Basin were the variations of the local base level, which are controlled itself by the climate changes. 